\title{
Investigation of Simple Portable Telescope Validity for Muon Detection Inside Metals
}

(Kajian Kesahihan Teleskop Mudah Alih untuk Mengesan Muon di dalam Logam)

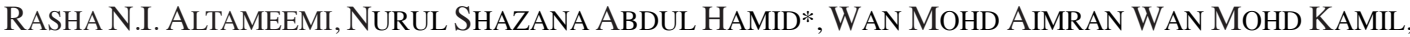 \\ SAAD M. SALEH AHMED \& GERI GOPIR
}

\begin{abstract}
Muons produced in the atmosphere by cosmic rays are preferred over gamma rays, X-rays and fast protons for the detection of metals in the study of radiography. An alternative method for metals detection involving portable and relatively cheap Geiger-Muller counters are proposed. The objective of this study was to investigate the validity of using a handmade muon telescope with a small solid angle for the detection of muons inside the metals. This experiment was carried out at Universiti Kebangsaan Malaysia, Bangi $\left(101.78^{\circ} \mathrm{E}, 2.92^{\circ} \mathrm{N}\right.$ and elevation $\left.30 \mathrm{~m}\right)$. Measurement of muons was conducted in the vertical direction using 1 set of muon telescopes (MT) consisting of coaxial Geiger-Muller (GM) counters. Different metals - lead (Pb), zinc ( $\mathrm{Zn})$ and aluminium $(\mathrm{Al})$ - were used as absorbers with different thickness to observe its influence on the count rate of muons. The efficiency of the experimental setup was evaluated using statistical methods and by obtaining sufficient number of muon detection events to describe the physics of the muon interaction with the metals. Based on the Rossi curve obtained for each metal, the transition point was estimated as follows: 1.5 $\mathrm{cm}$ for $\mathrm{Pb}, 4.0 \mathrm{~cm}$ for $\mathrm{Zn}$, and $9.0 \mathrm{~cm}$ for Al. The results showed that the proposed alternative setup was adequate for detecting muons and therefore have the potential to be further developed.
\end{abstract}

Keywords: Geiger-Muller counters; metal sheets; muon telescope; Rossi curve

ABSTRAK

Muon yang dihasilkan dalam atmosfera oleh sinar kosmik adalah lebih diutamakan daripada sinar gama, sinar-x dan proton berkelajuan tinggi sebagai pengesan logam dalam kajian radiografi. Satu kaedah alternatif untuk mengesan logam yang melibatkan penghitung Geiger-Muller mudah alih dan lebih murah dicadangkan. Objektif kajian ini adalah untuk mengkaji kesahihan menggunakan teleskop muon dengan sudut pejal yang kecil untuk pengesanan muon di dalam logam. Uji kaji ini telah dijalankan di Universiti Kebangsaan Malaysia, Bangi $\left(101.78^{\circ}\right.$ E, $2.92^{\circ}$ N pada ketinggian $30 \mathrm{~m}$ ). Pengukuran muon telah dijalankan pada arah menegak menggunakan 1 set teleskop muon (TM) yang terdiri daripada sepaksi penghitung Geiger-Muller (GM). Logam berbeza seperti plumbum (Pb), zink ( $\mathrm{Zn}$ ) dan aluminium (Al) telah digunakan sebagai penyerap dengan ketebalan berbeza untuk melihat pengaruhnya terhadap kadar kiraan muon. Persediaan percubaan uji kaji dinilai menggunakan kaedah statistik dan dengan mendapatkan bilangan kejadian pengesanan muоn yang mencukupi untuk menerangkan interaksi muon dengan logam. Berdasarkan lengkung Rossi yang diperoleh untuk setiap logam, titik peralihan dianggarkan seperti berikut: $1.5 \mathrm{~cm}$ untuk Pb, $4.0 \mathrm{~cm}$ bagi Zn dan $9.0 \mathrm{~cm}$ bagi Al. Keputusan menunjukkan bahawa persediaan alternatif yang dicadangkan mencukupi untuk mengesan muon dan berpotensi untuk dibangunkan.

Kata kunci: Kepingan logam; lengkung Rossi; penghitung Geiger-Muller; teleskop muon

\section{INTRODUCTION}

The muon, with mass 200 times the mass of the electron and generated in the atmosphere by the incoming protons from space, have high penetration ability. They arrived at the Earth's surface with high energies up to $100 \mathrm{TeV}$ that enable them to penetrate rocks about $100 \mathrm{~m}$ or a few kilometers thick (Bogdanov et al. 2006; Bonal et al. 2016, 2015). Therefore, muons as other rays protons and gamma rays, can be used in radiography (Procureur 2017). The use of muon in radiography is called muography (Bonal et al. 2016; Borozdin et al. 2003). The detection of metals is one of the important applications and essential for muography.
It prevents the transportation of illegal material between countries. For example, it is able to detect a cargo or a container containing an amount of uranium shielded with lead. Muography provides a technique to detect these materials but faces difficulties due to the complexity and high cost of this technology.

Previous studies showed that the muon is among the best particles to detect metals (Bogdanov et al. 2006; Priedhorsky et al. 2004). Gamma ray is quickly attenuating through these metals and can penetrate only a few centimeters. Fast protons can penetrate sufficiently but it needs accelerators that cost a lot and not portable. 
Both of them need a source of rays. However, muons are already available with sufficient intensity of about 10,000 muon/min-m2 measured at sea level (Borozdin et al. 2003) and it could used as an alternative to detect metals at lesser cost and more portability.

The detection of muon is a complex task because the interaction of muon with the metals consists of different processes (Fredrick 2016). A radial shower of scattered charged particle, mostly electrons, is yielded due to the multiple scattering of muons. From Bremsstrahlung, photons are produced with different energy depending on the muon energy. Hence, rays from two sources - first, from the muon and second, from the scattered electrons and high-energy photons - enter the detector and cause the count rate during the detection. This makes tracking and identifying the muon difficult by only one detector. Therefore, a muon telescope with at least two detectors with minimum detection area to avoid the spreading shower could be more efficient for detection and provide more accurate measures and that is our target in the present work. The minimum area of detection, the solid angle, can be adopted using a small number of synchronized detectors with minimum separation distances between the detectors.

Several counters were used for muon detection after passing through the metals such as scintillation detectors (Antonuccio et al. 2017; Eissa et al. 1967), cloud chamber detectors (Das Gupta \& Ghosh 1946; Tanaka 2008) and gaseous detectors (Dixit \& Rankin 2006; George et al. 1942). Early works used gaseous and scintillation counters with a few coincidences to ensure the measured count rate are caused by incident muons through the metals but within a large solid angle (Antonuccio et al. 2017; Brini et al. 1955; Eissa et al. 1967; Swann \& Ramsey 1940). Gas detectors (Geiger-Muller counters) were first used to obtain the count rate due to the ionizations caused by the muon interaction with the gas (George et al. 1942; Heyland \& Duncanson 1953; Jánossy \& Nagy 1957). It was proved that muon gaseous detectors can achieve higher resolution of detection than scintillation detectors with still reasonable cost (Bonolis 2011; Dixit \& Rankin 2006; Dupré, \& Aune 2013; Procureur 2017).

Tracking the muon inside the metal is still a crucial issue. Muon tracking in the metal has been studied in several researches. Traditionally, the detection of muons requires track detectors. However, the tracks made by the muon and other particles produced by its interactions is still complicated (Fomin et al. 2017). Fredrick (2016) reported that the Coulomb multi-scattering of muon inside the high-dense material causes potential trajectories that their tracking requires two systems of detectors synchronized with sufficient time resolution. He suggested that the attenuation information is sufficient or detection because such a system with this size and complexity is completely impractical for most suggested applications (Fredrick 2016).

Most works focused on complex muography more than material detection. Borozdin et al. (2003) first demonstrated the concept of muography by developing a small-scale experimental system made from four chamber detectors, to track the muon vertically by two and horizontally by another two (Borozdin et al. 2003). Reconstruction algorithm for an object image, based on the muon multi-scattering in both high and medium- $Z$ materials, was presented and compared to Monte Carlo simulation (Schultz et al. 2004). Since radiation length drops rapidly with atomic number, in traveling $10 \mathrm{~cm}$ a $3 \mathrm{GeV}$ muon will scatter, on the average, $2.3 \mathrm{mrad}$ in water, $11 \mathrm{mrad}$ in iron, and $20 \mathrm{mrad}$ in lead (Priedhorsky et al. 2004). Comparing the small amount of deflection in lead with the high range of energy of the incident muons, the design of such apparatus for the material detection is difficult and expensive especially when high technology is used to increase the angular resolution (Bonal et al. 2016). Therefore, no work has considered the cost effectiveness and portability in designing a muon telescope for metals detection yet.

In this work, the uses of GM counter to identify metals using muons is proposed. This proposal is not for muography or obtaining the dimension of the detected material. The charge particles (muons) heavier than electrons are more detectable than the electrons and photons by the GM counters in our study. In this study we run experiments to detect muons that penetrate through three different types of metals using a handmade muon telescope made from combining GM tubes. From the obtained count rate, we can characterize the transition point for each metal used. The transition points for each metal can be used as reference for muography work. The muon telescope consist of very small solid angle and double coincidence ( 2 coaxial GM tubes) which allowed the detection of highly penetrating particles only (i.e. muons) and excludes other rays. The interaction of muon inside the metal result in photons and electrons. The obtained count rate could be from these three particles, but this leads to reduce the number of the detection. We investigate the response of the detection system made from two GeigerMuller counters, with small detection of muons after it passes through different metals: lead, zinc and aluminum, with different thickness.

\section{MATERIALS AND METHODS}

This experiment measured the count rate caused by the muons that penetrating to different depths in different types of metal. It was carried out inside a laboratory at School of Applied Physics of Universiti Kebangsaan Malaysia, located at $101.78^{\circ} \mathrm{E}, 2.92^{\circ} \mathrm{N}$ and $30 \mathrm{~m}$ above sea level. The background of radiation of this place have been investigated by several previous studies such as Samat and Evans (2011), Tawalbeh et al. (2013) and Thabayneh (2016). All these studies reported that there is very small background radiation effect at the place of the study, thus, the current study is not required to subtract any radiation from the count rate. This can ensure that the experiment 
run smoothly without disturbance from any other source. The muon telescope (MT) consists of two RM60 radiation monitors RM1 and RM2 produced by Aware Electronics implemented to GM tubes of GM1 and GM2 as depicted in Figure 1(a). The two detectors were fixed over each other and placed vertically where the axes of the cylindrical ionization chamber GM tube are on one vertical line (Zain et al. 2010, 2009). The window of the GM tube has a density of 1.5 to $2.0 \mathrm{mg} / \mathrm{cm} 2$, effective diameter of 0.91 $\mathrm{cm}$ and effective area of $0.66 \mathrm{~cm}^{2}$. The distance from the lower end of the upper GM tube (GM1) to the upper end of the lower GM tube (GM2) is $7.19 \mathrm{~cm}$. Therefore, the solid angle can be calculated and found to be $0.05 \mathrm{sr}$ as shown in Figure 2. The wall of the GM tube has a thickness of $0.04 \mathrm{~cm}$, and effective length of $3.81 \mathrm{~cm}$. Both radiation monitors are connected to a coincidence box in order to determine the instantaneous radiation events that occur simultaneously. The output of the coincidence box is recorded and displayed on a computer monitor that works using Aw-Radw software for the real-time radiation data. The metal sheets with dimension of $20 \mathrm{~cm} \times 20 \mathrm{~cm}$ and different thickness used in the experiment are given in Table 1, were placed on the top of the housing box.
The incoming muons will pass through the ceiling that is made up of one layer of reinforced concrete before entering the top of the muon telescope located in the laboratory. The reinforced concrete ceiling and the walls of the laboratory have no contribution on muon detection because of their low density $\approx 2.3 \mathrm{~g} / \mathrm{cm}^{3}$ and a relatively small muon absorption coefficient $\boldsymbol{\alpha}$ of $(0.0001 \pm 0.00014$ $\mathrm{cm}^{-1}$ as measured in the reinforced concrete building (Ashnina 2012).

Since the solid angle is very small, it was important to verify that the readings of counts are statistically significant. The duration for collecting the counts was fixed to be $24 \mathrm{~h}$. The t-test was applied on the total daily muon counts were collected over a total period of seven days twice without shielding and the results showed that the paired sample t-test of the two sets of data have no significant mean difference in the population at 0.05 significance level. Because the measure of the current work was with different thickness of shielding, different types of metals and the counts per $24 \mathrm{~h}$ were collected for each thickness, these measures were also repeated to have two sets of data. The t-test of the two samples were applied to the two sets before using each type of metal shielding
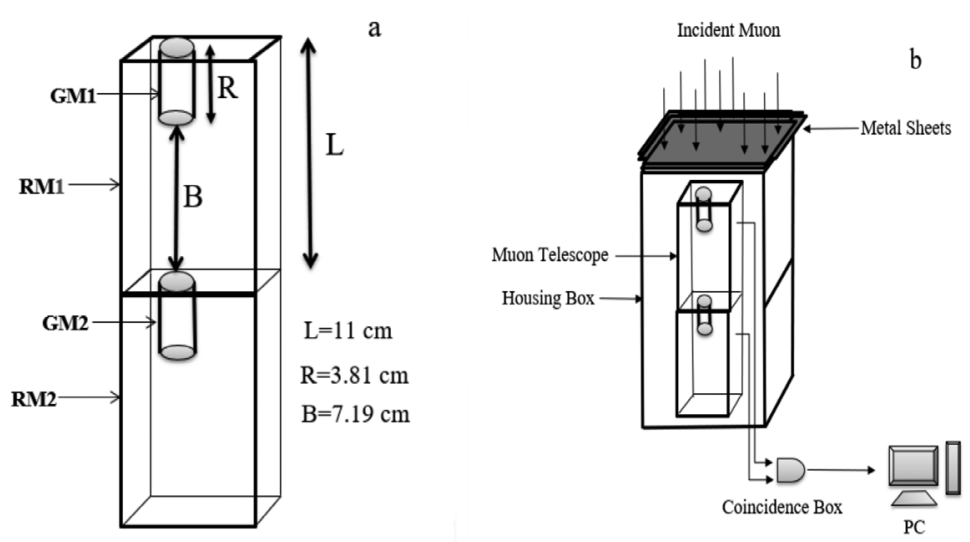

FIGURE 1. Schematic diagram of cosmic-ray muon experiment set up (a) Inside view of the muon telescope, MT and (b) Front view of the experiment set up

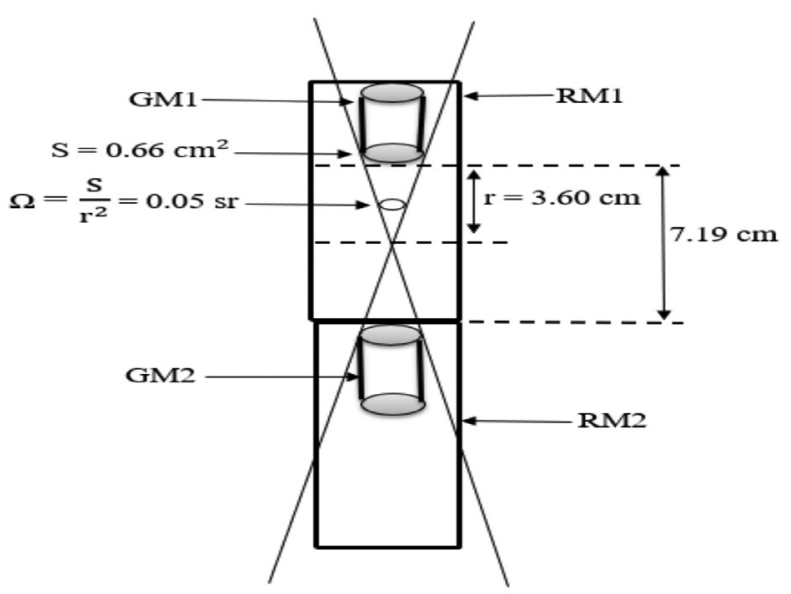

FIGURE 2. Schematic diagram of the solid angle, $\Omega$, for the muon telescope 
TABLE 1. Metal sheet thickness of different metals used in the experiment

\begin{tabular}{lll}
\hline $\mathrm{M}$ & Single sheet thickness & Total thickness $(\mathrm{cm})$ \\
\hline $\mathrm{Pb}$ & 140 sheets of $0.10 \mathrm{~cm}$ & 14.00 \\
$\mathrm{Zn}$ & 20 sheets of $0.15 \mathrm{~cm}$ & 17.40 \\
& 72 sheets of $0.20 \mathrm{~cm}$ & \\
$\mathrm{Al}$ & 20 sheets of $0.10 \mathrm{~cm}$ & 20.00 \\
& 90 sheets of $0.20 \mathrm{~cm}$ & \\
\hline
\end{tabular}

to be sure that the designed telescope was providing data with no significant difference.

\section{RESULTS AND DISCUSSION}

$$
\text { LEAD }
$$

In this experiment, we will first discuss the muon interaction with lead $(\mathrm{Pb})$. The muon count rate measured by the telescope when $\mathrm{Pb}$ shielding is used for different thickness is shown in Table 2. This set of data took 28 days and another set with similar measuring conditions was also collected (not shown here) and took another 28 days. The t-test for the two sets also showed no difference in the mean values of the two populations. The range of the count rate

TABLE 2. Count rate, $R$, of muon measured with different thickness, $\mathrm{x}$, of $\mathrm{Pb}$ shielding

\begin{tabular}{|c|c|}
\hline $\mathrm{x}(\mathrm{cm})$ & $\mathrm{R}$ (Count/h-sr) \\
\hline 0.0 & 31.68 \\
\hline 0.5 & 67.68 \\
\hline 1.0 & 74.16 \\
\hline 1.5 & 62.64 \\
\hline 2.0 & 61.92 \\
\hline 2.5 & 63.36 \\
\hline 3.0 & 52.56 \\
\hline 3.5 & 54.72 \\
\hline 4.0 & 41.04 \\
\hline 4.5 & 40.32 \\
\hline 5.0 & 39.60 \\
\hline 5.5 & 35.82 \\
\hline 6.0 & 38.88 \\
\hline 6.5 & 31.68 \\
\hline 7.0 & 29.52 \\
\hline 7.5 & 41.76 \\
\hline 8.0 & 40.32 \\
\hline 8.5 & 47.52 \\
\hline 9.0 & 38.88 \\
\hline 9.5 & 33.12 \\
\hline 10.0 & 41.76 \\
\hline 10.5 & 38.16 \\
\hline 11.0 & 41.76 \\
\hline 11.5 & 36.00 \\
\hline 12.0 & 42.48 \\
\hline 12.5 & 33.84 \\
\hline 13.0 & 30.96 \\
\hline 13.5 & 27.36 \\
\hline 14.0 & 30.96 \\
\hline
\end{tabular}

is $27-74$ count/h-sr which is close to earlier measures using different solid angles and different number of coincidences (George et al. 1942; Jánossy \& Nagy 1957; Nagy 1958).

The count rate versus thickness of the $\mathrm{Pb}$ shielding is depicted in Figure 3. This graph is called the Rossi curve that has a familiar behavior of fast growth until a maximum point called the transition point. Then the count rate starts to decay exponentially. The exponential decay is well studied and explained as the exponential attenuation of muon energy. Different shielding material with different atomic number have a different coefficient of attenuation values (George et al. 1942; Jánossy \& Nagy 1957; Nagy 1958). Obtaining a Rossi curve for Pb sheets indicates the validity of the muon telescope for very small solid angle. By applying an extreme fit to the Rossi curve, the value of the transition point can be extracted and is found to be 1.5 $\mathrm{cm}$. This value is the same as the value obtained from an earlier work (George et al. 1942). This agreement validates the experimental setup to measure muon count rates. In addition, this agreement demonstrates that the efficiency of this two-counters setup to be comparable to multiple counters setup used in previous works.

\section{ZINC}

Zinc was the second metal we investigated using the muon telescope. We applied the same analysis of $\mathrm{Pb}$ with $\mathrm{Zn}$ and the results are shown in Table 3. Another set of results not mentioned in this study was obtained for $\mathrm{Zn}$. The range of the muon count rate (39-72 count/h-sr) is similar to that of earlier work as in the $\mathrm{Pb}$. The behavior of the count rate

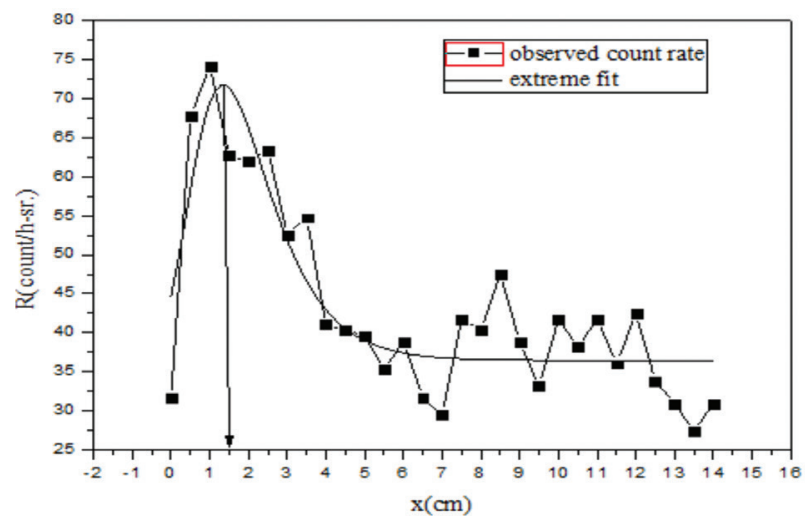

FIGURE 3. Muon count rate, $\mathrm{R}$, behaviour with increasing the $\mathrm{Pb}$ shield thickness, $\mathrm{x}$. The transition point is at $1.5 \mathrm{~cm}$ 
TABLE 3. Count rate, $R$, of muon measured with different thickness, $\mathrm{x}$, of $\mathrm{Zn}$ shielding

\begin{tabular}{cc}
\hline $\mathrm{x}(\mathrm{cm})$ & $\mathrm{R}($ Count $/ \mathrm{h}-\mathrm{sr})$ \\
\hline 0.0 & 50.47 \\
1.0 & 52.41 \\
2.0 & 51.69 \\
3.0 & 58.68 \\
4.0 & 72.21 \\
5.0 & 58.96 \\
6.0 & 57.96 \\
7.0 & 56.44 \\
8.5 & 65.23 \\
9.0 & 56.95 \\
10.0 & 45.00 \\
11.0 & 49.53 \\
12.0 & 62.13 \\
13.0 & 39.96 \\
14.0 & 51.48 \\
15.0 & 39.24 \\
16.0 & 46.80 \\
17.0 & 49.32 \\
17.4 & 37.80 \\
\hline
\end{tabular}

with the depth of the $\mathrm{Zn}$ sheets is shown in Figure 4. The transition point at the first peak is very clear and equal to $4.0 \mathrm{~cm}$. The deeper starting point of attenuation indicates that zinc is not a good absorber to cosmic ray shower as $\mathrm{Pb}$. The appearance of the transition point depends on metal atomic number and density which indicates the capability of the telescope to well measure the count rate when the solid angle is very small.

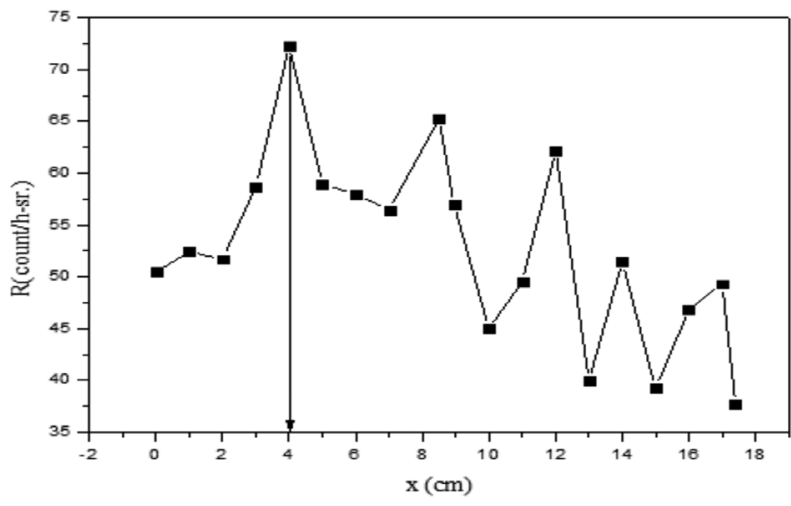

FIGURE 4. Muon count rate, $\mathrm{R}$, behaviour with increasing the $\mathrm{Zn}$ shield thickness, $\mathrm{x}$. The transition point is at $4 \mathrm{~cm}$

\section{ALUMINIUM}

Aluminium was the third metal we investigated in this study using the same procedure for $\mathrm{Pb}$ and $\mathrm{Zn}$. The results are shown in Table 4. The statistical significance was also investigated using another set of reads same to the previous metals, which showed no difference. The transition point was clearly observed at $9.0 \mathrm{~cm}$ (Figure 5), that is greater
TABLE 4. Count rate, $R$, of muon measured with different thickness, $\mathrm{x}$, of $\mathrm{Al}$ shielding

\begin{tabular}{cc}
\hline $\mathrm{x}(\mathrm{cm})$ & $\mathrm{R}($ Count $/ \mathrm{h}-\mathrm{sr})$ \\
\hline 0.0 & 51.84 \\
1.0 & 48.96 \\
2.0 & 43.20 \\
3.0 & 51.84 \\
4.0 & 48.96 \\
5.0 & 56.16 \\
6.0 & 54.72 \\
7.0 & 48.24 \\
8.0 & 54.72 \\
9.0 & 64.80 \\
10.0 & 52.56 \\
11.0 & 50.40 \\
12.0 & 58.32 \\
13.0 & 47.52 \\
14.0 & 54.00 \\
15.0 & 39.60 \\
16.0 & 64.08 \\
17.0 & 53.28 \\
18.0 & 50.40 \\
19.0 & 54.00 \\
20.0 & 50.40 \\
\hline
\end{tabular}

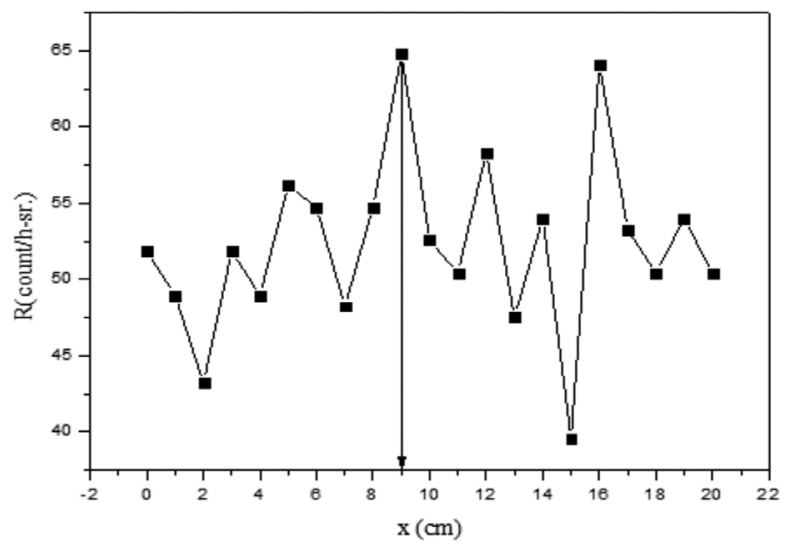

FIGURE 5. Muon count rate, $\mathrm{R}$, behaviour with increasing the depth of the $\mathrm{Al}$ shield thickness, $\mathrm{x}$. The transition point is at $9 \mathrm{~cm}$

than those of $\mathrm{Pb}$ and $\mathrm{Zn}$ because of its lower density and lower atomic number $(Z=13)$. The behavior after the transition point is also exponentially decreasing as the previous metals to indicate the decay of muon energy inside the metal.

It is important to notice that the transition point of $\mathrm{Al}$ $(Z=13)$ is twice that of $Z n(Z=30)$ and the transition point of $\mathrm{Zn}$ is about twice that $\mathrm{Pb}(\mathrm{Z}=82)$ as shown in Table 5 . This means that the transition point is deeper when metal of lower atomic number $\mathrm{Z}$ is used. This relationship agree with an earlier work by Nagy (1958).

Such agreement in the relationship between the results of the current work and the previous work reflect the efficiency of the proposed telescope to measure cosmic ray muons. In addition, for more comparison among the shielding metal of different $\mathrm{Z}$, the ratio of the atomic 
TABLE 5. Ttransition point, T, and atomic number, Z, of different metals used in the experiment

\begin{tabular}{ccc}
\hline $\mathrm{M}$ & Transition point $(\mathrm{T})$ & Atomic number $(\mathrm{Z})$ \\
\hline $\mathrm{Pb}$ & 1.5 & 82 \\
$\mathrm{Zn}$ & 4.0 & 30 \\
$\mathrm{Al}$ & 9.0 & 13 \\
\hline
\end{tabular}

numbers of two elements is about equal to the reciprocal ratio of their transition points, as follows,

$$
\begin{aligned}
& \frac{Z(P b)}{Z(Z n)}=2.73 \approx \frac{T(Z n)}{T(P b)}=2.67 \\
& \frac{Z(Z n)}{Z(A l)}=2.31 \approx \frac{T(A l)}{T(Z n)}=2.25
\end{aligned}
$$

The approximate similarity in the ratios confirms the capability of the proposed telescope to measure the count rate of the cosmic shower as other telescopes with large acceptance (Altameemi \& Gopir 2016).

In summary, all the previous measurements, the range of measured count rate, the statistical test, the transition point in the Rossi curves and the correlation between the transition points and the atomic number of the shielding materials demonstrates the efficiency of the proposed telescope for measuring cosmic ray muons.

\section{CONCLUSION}

In this study, the efficiency of a muon telescope with a small acceptance and double coincidence was investigated. The muon count rates obtained were comparable to earlier works using telescopes with larger acceptance and larger number of coincidences. Although a lower number of muon count rates were obtained in our study due to its smaller acceptance, this does not alter the demonstrated efficiency of our muon telescope.

\section{ACKNOWLEDGEMENTS}

The authors wish to thank Universiti Kebangsaan Malaysia (UKM), for the lab facilities. Nurul Shazana is supported by grant GUP-2016-016.

\section{REFERENCES}

Altameemi, R.N.I. \& Gopir, G. 2016. Effect of copper and aluminium on the event rate of cosmic ray muons at ground level in Bangi, Malaysia. AIP Conference Proceedings 2016 1784: 040005

Antonuccio, V., Bandieramonte, M., Becciani, U., Bonanno, D.L., Bonanno, G., Bongiovanni, D., Fallica, P.G., Garozzo, S., Grillo, A., Rocca, P.La., Leonora, E., Longhitano, F., Presti, D.Lo., Marano, D., Parasole, O., Pugliatti, C., Randazzo, N., Riggi, F. \& Valvo, G. 2017. The muon portal project: Design and construction of a scanning portal based on muon tomography. Nuclear Instruments and Methods in Physics Research Section A: Accelerators, Spectrometers, Detectors and Associated Equipment 845: 322-325.

Ashnina, H.M.A. 2012. Effect of sheilding building on muon events at ground level. MSc Thesis, School of Physics. Bangi: Universiti Kebangsan Malaysia (Unpublished).

Bogdanov, A.G., Burkhardt, H., Ivanchenko, V.N., Kelner, S.R., Kokoulin, R.P., Maire, M., Rybin, A.M. \& Urban, L. 2006. Geant4 simulation of production and interaction of Muons. IEEE Transactions on Nuclear Science 53(2): 513-519.

Bonal, N.D., Iv, A.T.C., Cieslewski, G., Dorsey, D.J., Foris, A., Green, J.A., Miller, T.J., Preston, L.A., Roberts, B.L., Schwellenbach, D. \& Su, J.C. 2016. Using muons to image the subsurface. Sandia Report.pp. 1-64.

Bonal, N.D., Preston, L.A., Dorsey, D.J., Schwellenbach, D., Dreesen, W. \& Green, J.A. 2015. Muon Technology for Geophysical Applications. Sandia National Laboratories (SNL-NM). Albuquerque, NM (United States).

Bonolis, L. 2011. Walther Bothe and Bruno Rossi: The birth and development of coincidence methods in cosmic-ray physics. Am.J. Phys. 79(11): 1133-1150.

Borozdin, K.N., Hogan, G.E., Morris, C., Priedhorsky, W.C., Saunders, A., Schultz, L.J. \& Teasdale, M.E. 2003. Surveillance: Radiographic imaging with cosmic-ray muons. Nature 422: 277-278.

Brini, D., Peli, L., Rimondi, O. \& Veronesi, P. 1955. Absolute lowenergy differential range spectrum of cosmic ray $\mu$-mesons at sea-level. Il Nuovo Cimento (1955-1965) 2(3): 613-638.

Das Gupta, N.N. \& Ghosh, S.K. 1946. A report on the wilson cloud chamber and its applications in physics. Reviews of Modern Physics 18(2): 225-365.

Dixit, M.S. \& Rankin, A. 2006. Simulating the charge dispersion phenomena in micro pattern gas detectors with a resistive anode. Nuclear Instruments and Methods in Physics Research, Section A: Accelerators, Spectrometers, Detectors and Associated Equipment 566(2): 281-285.

Dupré, R. \& Aune, S. 2013. Genetic multiplexing and first results with a $50 \times 50 \mathrm{~cm}^{2}$ Micromegas. Nuclear Instruments and Methods in Physics Research Section A: Accelerators, Spectrometers, Detectors and Associated Equipment 729: 888-894.

Eissa, N.A., Berényi, D., Máthé, G., Varga, D., Řezanka, I. \& Malý, L. 1967. New higher levels of $144 \mathrm{Nd}$ in the decay of 144Pm. Nuclear Physics A 100(2): 438-448.

Fomin, Y.A., Kalmykov, N.N., Karpikov, I.S., Kulikov, G.V., Kuznetsov, M.Y., Rubtsov, G.I., Sulakov, V.P. \& Troitsky, S.V. 2017. No muon excess in extensive air showers at 100$500 \mathrm{PeV}$ primary energy: EAS-MSU results. Astroparticle Physics 92: 1-6.

Fredrick, H.S. 2016. Methods and simulations of muon tomography and reconstruction. The University of Texas at Austin (Unpublished).

George, E.P., Jánossy, L. \& McCaig, M. 1942. The 'second maximum' of the shower transition curve of cosmic radiation. Proc. R. Soc. Lond. A 180: 219-224.

Heyland, G.R. \& Duncanson, W.E. 1953. A search for irregularities in the absorption of cosmic rays in lead. Proceedings of the Physical Society: Section A 66(1): 33.

Jánossy, L. \& Nagy, L. 1957. Experiments on the Rossi curve. Acta Physica Academiae Scientiarum Hungaricae 6(3): 467.

Nagy, L. 1958. Shower production at small thicknesses of absorber. Acta Physica Academiae Scientiarum Hungaricae 9(1): 63-72. 
Priedhorsky, W.C., Borozdin, K.N., Hogan, G.E., Morris, C., Saunders, A., Schultz, L.J. \& Teasdaleb, M.E. 2004. Detection of high-z objects using multiple scattering of cosmic ray muons. AIP Conference Proceedings 698: 755-758.

Procureur, S. 2017. Muon imaging: Principles, technologies and applications. Nuclear Instruments and Methods in Physics Research, Section A: Accelerators, Spectrometers, Detectors and Associated Equipment 878: 169-179.

Samat, S.B. \& Evans, C.J. 2011. Determination of radiation hazard arising from the $40 \mathrm{~K}$ content of bottled mineral water in Malaysia. Sains Malaysiana 40(12): 1355-1358.

Schultz, L.J., Borozdin, K.N., Gomez, J.J., Hogan, G.E., McGill, J.A., Morris, C.L., Priedhorsky, W.C., Saunders, A. \& Teasdale, M.E. 2004. Image reconstruction and material Z discrimination via cosmic ray muon radiography. Nuclear Instruments and Methods in Physics Research, Section A: Accelerators, Spectrometers, Detectors and Associated Equipment 519(3): 687-694.

Swann, W.F.G. \& Ramsey, W.E. 1940. The secondary peak in the Rossi curvi for tin. Phys. Rev. 477: 661-663.

Tanaka, H.K.M., Nakano, T., Takahashi, S., Yoshida, J., Takeo, M., Oikawa, J., Ohminato, T., Aoki, Y., Koyama, E., Tsuji, H., Ohshima, H., Maekawa, T., Watanabe, H. \& Niwa, K. 2008. Radiographic imaging below a volcanic crater floor with cosmic-ray muons. American Journal of Science 308: 843-850.

Tawalbeh, A.A., Samat, S.B. \& Yasir, M.S. 2013. Radionuclides level and its radiation hazard index in some drinks consumed in the central zone of Malaysia. Sains Malaysiana 42(3): 319-323.

Thabayneh, K.M. 2016. Determination of alpha particles concentration in some soil samples and the extent of their impact on health. Sains Malaysiana 45(5): 699-707.
Zain, N.M., Gopir, G.K., Yatim, B., Sanusi, H. \& Husain, N.H. 2010. Observation of ground level muon at Bangi in 20082009. AIP Conference Proceedings 1250: 468-471.

Zain, N.M., Gopir, G.K., Yatim, B., Sanusi, H. \& Husaina, N.H. 2009. Zenith angle dependence of muon rate at ground level in Bangi. International Conference on Space Science and Communication, IconSpace - Proceedings. pp. 191-194.

Rasha N.I. Altameemi, Nurul Shazana Abdul Hamid* \& Wan Mohd Aimran Wan Mohd Kamil \& Geri Gopir School of Applied Physics

Faculty of Science and Technology

Universiti Kebangsaan Malaysia

43600 UKM Bangi, Selangor Darul Ehsan Malaysia

Saad M. Saleh Ahmed

Department of Physics, Faculty of Science

University of Malaya

50603 Kuala Lumpur, Federal Territory

Malaysia

*Corresponding author; email: shazana.ukm@gmail.com

Received: 14 April 2018

Accepted: 4 October 2018 